\title{
Serum IGF-binding protein- 6 and prostate specific antigen in breast cancer
}

\author{
Karmal K Kaulsay ${ }^{1}, \mathrm{E} \mathrm{H} \mathrm{Ng}^{3}$, C Y Ji ${ }^{3}$, G H Ho ${ }^{3}$, $\mathrm{T} \mathrm{C} \mathrm{Aw}^{2}$ and Kok-Onn Lee ${ }^{1}$ \\ Departments of ${ }^{1}$ Medicine and ${ }^{2}$ Pathology, National University of Singapore, Singapore 119074 and ${ }^{3}$ Department of Surgery, Singapore General \\ Hospital, Singapore \\ (Correspondence should be addressed to K-O Lee, Division of Endocrinology, Department of Medicine, National University of Singapore, Kent Ridge \\ Road, Singapore 119074)
}

\begin{abstract}
Objective: Recent studies have demonstrated the presence of the IGF-binding proteins (IGFBPs) and prostate specific antigen (PSA), an IGFBP protease, in human breast tissue. We sought to investigate the differences in serum IGFs, IGFBP-1, -3 and -6 , and PSA between patients with surgically proven breast cancer and patients with benign breast disease.

Design and Methods: Concentrations of IGFs, IGFBP-1, -3 and -6 , and PSA were determined in the sera from 57 patients with breast cancer (CA), and 46 women with benign breast disease (BBD) using immunoassays for IGFs and IGFBPs and an ultrasensitive ELISA for PSA.

Results: The mean ( \pm s.E.M.) serum IGFBP-6 level in the CA group, 127 (16) ng/ml, was statistically significantly lower than in the BBD group, $157(10) \mathrm{ng} / \mathrm{ml}(P=0.016)$. Patients with CA had an elevated geometric mean serum PSA level of 0.018 (range: $0.0015-0.107$ ) $\mathrm{ng} / \mathrm{ml}$, compared with 0.007 (range: $0.0015-0.019) \mathrm{ng} / \mathrm{ml}$ in women with BBD $(P=0.025)$. Mean serum IGFBP-1 concentrations were significantly lower in the CA group, $16(2) \mathrm{ng} / \mathrm{ml}$, versus $37(4) \mathrm{ng} / \mathrm{ml}$ in the BBD group $(P=0.001)$. Mean serum IGFBP-3 concentrations were also lower in the CA group versus the BBD group, at $1981(65) \mathrm{ng} / \mathrm{ml}$, versus $2603(140) \mathrm{ng} / \mathrm{ml}(P=0.002)$ respectively. In the CA group, statistically significant correlations between PSA and IGFBP-6 $(r=0.413 ; P=0.001)$, and between PSA and IGFBP-1 $(r=-0.329 ; P=0.021)$ were seen. Differences in IGF-I and -II between the two groups were not statistically significant.

Conclusion: Lower serum concentrations of IGFBP-6, -3 and -1, but higher PSA concentrations were seen in the breast cancer group, and collectively these would suggest that there is an increase in bioavailable IGF-I in breast cancer.
\end{abstract}

European Journal of Endocrinology 140 164-168

\section{Introduction}

Breast cancer is the most common female cancer and is a leading cause of mortality in women. Recent findings have shown that the insulin-like growth factors (IGFs) and their associated binding proteins, the IGF-binding proteins (IGFBPs), are involved in cancer cell proliferation. Both IGF-I and IGF-II have been shown to be potent mitogens for transformed breast epithelial cells (1-3). In addition, recent findings have suggested that higher plasma levels of IGF-I are a significant risk factor for the subsequent development of breast cancer (4), and of prostate cancer (5). The IGFs are predominantly bound in serum and various body fluids with differential affinities to the family of IGFBPs, which have been shown to modulate their biological activity in several experimental systems (6-8). Early studies attributed the growth modulatory action of the IGFBPs to the competitive binding of IGF-I and/or IGF-II thus reducing the bioavailability of the free peptide for the IGF receptors (9). However, more recent evidence points to a direct role for IGFBP-3 growth inhibition independent of its IGF-binding properties (10-12). Other IGFBPs have been less well studied, partly due to the unavailability of specific antibodies.

In addition, the kallikrein glycoprotein prostate specific antigen (PSA), a known protease of IGFBP-3 (13, 14), has recently been identified in breast tumors (15) and in healthy normal female breast (16). In the present study, we have attempted to evaluate the role of some of these factors in breast cancer and have used newly available assays to measure serum levels of IGFBP-6, a relatively newly characterized member of the IGFBP family which has a strong preferential affinity for IGF-II (17), and PSA, a known IGFBP protease. We also measured serum levels of IGFBP-3, IGFBP-1, and total IGF-I and IGF-II in our study populations of women with breast cancer and in a control group of women with surgically proven benign breast disease. 


\section{Subjects and methods}

\section{Subjects}

A group of women with breast cancer $(C A, n=57)$ and a control group of women with benign breast disease (BBD, $n=46$ ) were recruited as our study populations. The women were similar in menopausal age and status, and were considered postmenopausal if menses had ceased spontaneously at least 6 months earlier. The breast cancer group consisted of 57 women with primary breast cancer (mean 53.6 years, standard deviation 9.5). No member of the breast cancer group of women had had preoperative chemotherapy or radiotherapy, nor did any cancer patient report any significant weight loss subjectively. The control group of women was selected from a national breast cancer mammography screening trial, all of whom underwent surgical biopsies over the same time-period for mammographic abnormalities. These patients were all confirmed to have benign breast disease on histology (mean 54.0 years, standard deviation 6.1).

Serum was collected after overnight fast immediately prior to surgery from both groups of women and transported to the laboratory where they were aliquoted and stored at $-70{ }^{\circ} \mathrm{C}$ until assays were performed.

The study was approved by the institutional and national review boards.

\section{Assays}

Serum IGFBP-1, IGFBP-3, IGFBP-6, and IGF-I and IGF-II were measured with immunoassay kits from Diagnostic Systems Laboratories (TX, USA). Assays were performed following the manufacturer's instructions. All the samples were assayed for each IGFBP/IGF in a single assay and the intra-assay coefficients of variation were all $<10 \%$. Total PSA was measured in a single batch using an ultrasensitive ELISA assay (Abbott Laboratories, IL, USA) with an analytical sensitivity of $0.003 \mathrm{ng} / \mathrm{ml}$ and an intra-assay coefficient of variation of $<10 \%$ at $0.005 \mathrm{ng} / \mathrm{ml}$. PSA values that were below $0.003 \mathrm{ng} / \mathrm{ml}$ were assigned a value of $0.0015 \mathrm{ng} / \mathrm{ml}$. No more than $5 \%$ of the total number of samples in both groups of women fell below the $0.003 \mathrm{ng} / \mathrm{ml}$ level. The
IGFBP-3 assay measures both intact and proteolyzed fragments of IGFBP-3 (18) and serum samples for IGFBP-3 analysis required a 100-fold dilution prior to assay. Serum samples for IGFBP-6 analysis required a 20-fold dilution prior to assay. Cross-reactivity between the IGFBP-6 and IGFBP-1 assays with IGFBP-3 was less than $0.02 \%$. (An IGFBP-3 concentration of $5 \mu \mathrm{g} / \mathrm{ml}$ was not detectable with either the IGFBP-6 or IGFBP-1 assays with sensitivities of $1.1 \mathrm{ng} / \mathrm{ml}$ and $0.33 \mathrm{ng} / \mathrm{ml}$ respectively.)

\section{Statistical analyses}

The unpaired Student's $t$-test for statistical significance was used to compare the means of measurements between two groups. For serum PSA, which had a skewed distribution, calculations were performed after natural logarithmic transformation $(1+\ln x)$, and the geometric means were calculated from the anti-log. The Spearman correlation coefficients were calculated for any two measurements within the breast cancer and the benign breast disease groups of women. All data analyses were performed using the Statistical Analysis Systems package (version 6.11; SAS Institute Inc, NC, USA).

\section{Results}

The mean ( \pm s.e.m.) serum concentrations of all the measurements in the two groups (CA and BBD) are shown in Table 1. Statistically significant differences between the two groups $(P<0.05)$ were seen in the mean serum concentrations of IGFBP-6, IGFBP-3, IGFBP-1, and total PSA. The mean serum IGFBP-6 level in the CA group, 127 (16) ng/ml, was statistically significantly lower compared with the control BBD group, $157(10) \mathrm{ng} / \mathrm{ml}(P=0.016$, Table 1 , see also Fig. 1). Similarly, both the mean serum IGFBP-3 and IGFBP-1 levels were significantly lower in the CA group $(P=0.002$, Table 1) compared with the BBD group. Thus both IGFBP-3, which is the main IGFBP in serum, and IGFBP-1 were significantly lower; and IGFBP-6, which has a much higher selective affinity for IGF-II, was also lower in the CA group of patients.

Table 1 Mean ( \pm S.E.M) serum measurements in patients with breast cancer and with benign breast disease. For PSA, because of the skewed distribution, the geometric mean is reported.

\begin{tabular}{lccrrrr}
\hline & \multicolumn{7}{c}{$\begin{array}{c}\text { Breast cancer } \\
(n=57)\end{array}$} & $\begin{array}{c}\text { Benign breast disease } \\
(n=46)\end{array}$ & $P$ value \\
\hline IGFBP-1 & $(\mathrm{ng} / \mathrm{ml})$ & 16 & $(2)$ & 37 & $(4)$ & 0.001 \\
IGFBP-3 & $(\mathrm{ng} / \mathrm{ml})$ & 1981 & $(65)$ & 2603 & $(140)$ & 0.002 \\
IGFBP-6 & $(\mathrm{ng} / \mathrm{ml})$ & 127 & $(16)$ & 157 & $(10)$ & 0.016 \\
Total IGF-I & $(\mathrm{ng} / \mathrm{ml})$ & 147 & $(12)$ & 161 & $(22)$ & 0.581 \\
Total IGF-II & $(\mathrm{ng} / \mathrm{ml})$ & 667 & $(22)$ & 668 & $(47)$ & 0.993 \\
PSA & $(\mathrm{ng} / \mathrm{ml})$ & \multicolumn{2}{c}{0.018} & 0.007 & 0.023 \\
\hline
\end{tabular}




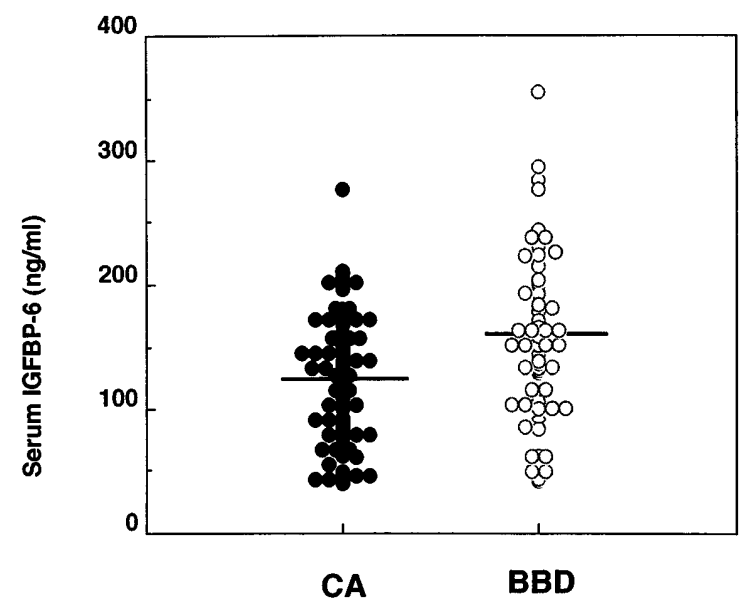

Figure 1 Scatter plot of serum IGFBP-6 of individual patients. The mean of each group is indicated. CA $(\bullet)$; BBD (O).

The geometric mean serum total PSA in the CA group, $0.018 \mathrm{ng} / \mathrm{ml}$, was significantly elevated compared with the control BBD group of women, $0.007 \mathrm{ng} / \mathrm{ml}$ $(P=0.023$, Table 1 , see also Fig. 2). The differences between the two study groups in mean serum total IGF-I and IGF-II were not statistically significant.

The correlations between any two measurements within the CA group are shown in Table 2. The strongest correlation seen was between the serum levels of IGFBP- 6 and serum total PSA $(r=0.413, P=$ 0.001). A less significant (inverse) correlation, between serum IGFBP-1 and PSA, was also statistically significant $(r=-0.329, P=0.021)$. None of the correlations between the other measurements in CA patients was

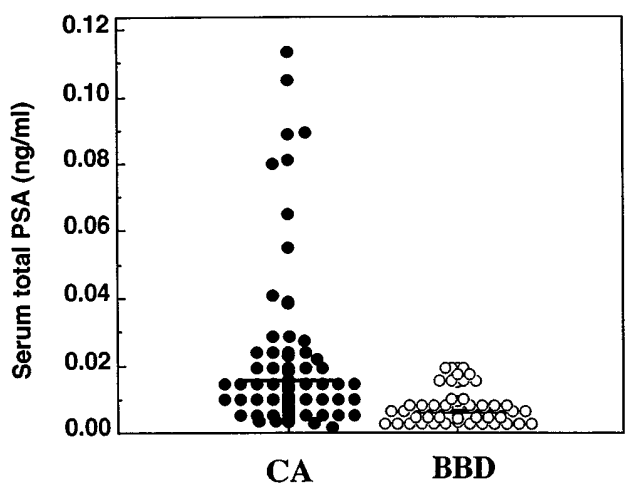

Figure 2 Scatter plot of serum total PSA of individual patients. The geometric mean of each group is indicated. CA (๑); BBD (O).

statistically significant. In contrast, in the BBD group of women, none of the correlations between any two measurements was statistically significant (data not shown).

\section{Discussion}

There has been an increasing body of evidence that suggests that the IGFs and the IGFBPs may be involved in human breast cancer. Studies using cell lines have shown that IGF-I, IGF-II and several IGFBPs have growth-regulatory properties $(2,3,12)$. Several studies have demonstrated the presence of IGF-I (19), IGF-II (20) and the IGFBPs $1-5$ in normal human breast, and in breast cancer tissues $(21,22)$. The IGFBP proteases, PSA and cathepsin-D, have also been similarly demonstrated in breast cancer tissues $(15,23,24)$. In the

Table 2 Spearman correlation analysis in patients with breast cancer.

\begin{tabular}{|c|c|c|c|c|c|c|}
\hline & IGF-I & IGF-II & IGFBP-1 & IGFBP-3 & IGFBP-6 & PSA \\
\hline IGF-I & & & & & & \\
\hline $\begin{array}{l}r \text { value } \\
P \text { value }\end{array}$ & $\begin{array}{c}1.000 \\
-\end{array}$ & $\begin{array}{c}-0.112 \\
\text { NS }\end{array}$ & $\begin{array}{c}0.054 \\
\text { NS }\end{array}$ & $\begin{array}{c}0.092 \\
\text { NS }\end{array}$ & $\begin{array}{c}-0.046 \\
\text { NS }\end{array}$ & $\begin{array}{c}-0.069 \\
\text { NS }\end{array}$ \\
\hline $\begin{array}{l}\text { IGF-II } \\
r \text { value } \\
P \text { value }\end{array}$ & $\begin{array}{c}-0.112 \\
\text { NS }\end{array}$ & $\begin{array}{c}1.000 \\
-\end{array}$ & $\begin{array}{l}0.136 \\
\text { NS }\end{array}$ & $\begin{array}{c}0.215 \\
\text { NS }\end{array}$ & $\begin{array}{c}-0.124 \\
\text { NS }\end{array}$ & $\begin{array}{c}-0.009 \\
\text { NS }\end{array}$ \\
\hline $\begin{array}{l}\text { IGFBP-1 } \\
r \text { value } \\
P \text { value }\end{array}$ & $\begin{array}{l}0.054 \\
\text { NS }\end{array}$ & $\begin{array}{l}0.136 \\
\text { NS }\end{array}$ & $\begin{array}{c}1.000 \\
-\end{array}$ & $\begin{array}{c}0.045 \\
\text { NS }\end{array}$ & $\begin{array}{c}-0.065 \\
\text { NS }\end{array}$ & $\begin{array}{r}-0.329 \\
0.021^{*}\end{array}$ \\
\hline $\begin{array}{l}\text { IGFBP-3 } \\
r \text { value } \\
P \text { value }\end{array}$ & $\begin{array}{l}0.092 \\
\text { NS }\end{array}$ & $\begin{array}{l}0.215 \\
\text { NS }\end{array}$ & $\begin{array}{l}0.045 \\
\text { NS }\end{array}$ & $\begin{array}{c}1.000 \\
-\end{array}$ & $\begin{array}{l}0.145 \\
\mathrm{NS}\end{array}$ & $\begin{array}{l}0.235 \\
\text { NS }\end{array}$ \\
\hline $\begin{array}{l}\text { IGFBP-6 } \\
r \text { value } \\
P \text { value }\end{array}$ & $\begin{array}{c}-0.046 \\
\text { NS }\end{array}$ & $\begin{array}{c}-0.124 \\
\text { NS }\end{array}$ & $\begin{array}{c}-0.065 \\
\text { NS }\end{array}$ & $\begin{array}{c}0.145 \\
\text { NS }\end{array}$ & $\begin{array}{l}1.000 \\
-\end{array}$ & $\begin{array}{l}0.413 \\
0.001^{*}\end{array}$ \\
\hline $\begin{array}{l}\text { PSA } \\
r \text { value } \\
P \text { value }\end{array}$ & $\begin{array}{c}-0.069 \\
\text { NS }\end{array}$ & $\begin{array}{l}0.009 \\
\text { NS }\end{array}$ & $\begin{array}{r}-0.329 \\
0.021^{*}\end{array}$ & $\begin{array}{c}0.235 \\
\text { NS }\end{array}$ & $\begin{array}{l}0.413 \\
0.001^{*}\end{array}$ & $\begin{array}{c}1.000 \\
-\end{array}$ \\
\hline
\end{tabular}

* Statistically significant; NS = not statistically significant. 
present study, we have compared prospectively the serum measurements of IGFBP- $6,-3$ and -1 , IGF-I and -II, and total PSA, using recently developed immunoassays, between two groups of women who underwent surgery for abnormalities found on mammography screening for breast cancer. Our study has shown significant differences in serum measurements that together suggest an increase in bioavailable IGF-I and IGF-II in patients with breast cancer.

The present study reports for the first time a significantly lower mean serum IGFBP-6 concentration in women with breast cancer. There are no previous studies on serum IGFBP-6 in cancer patients, as specific immunoassays (25) have only recently become available. IGFBP-6 differs from the other IGFBPs in the absence of a conserved local motif within the N-terminal region, and has a much greater affinity for IGF-II than for IGF-I, unlike the other IGFBPs (26). A lower serum concentration of IGFBP-6, in the presence of similar serum total IGF-II concentrations, would be consistent with the suggestion of an increase in the bioavailable IGF-II in the breast cancer patients compared with the controls. This finding might be important in light of the demonstrated role of IGF-II in cell culture systems in the regulation of growth of breast cancer cells $(2,27)$.

Our study found significant differences in IGFBP-3 and IGFBP-1 mean concentrations in our breast cancer patients. Previous studies of IGFBP-3 in breast cancer have reported conflicting results of a lower (28), higher (29), or no difference in serum values (30) compared with control groups. Our study found a statistically significantly lower mean serum IGFBP-3 level in breast cancer patients and supports a recent large prospective study which found an inverse relationship between serum IGFBP-3 concentrations and breast cancer risk (4). The use of differing immunoassays in the previous studies might explain some of the discrepancy. Another possibility might be the selection criteria of the women used as controls in our study, in that all of them had identical clinical criteria to the breast cancer group prior to obtaining histological diagnosis.

Our study also found a significantly lower serum IGFBP-1 concentration in our breast cancer group of women, which has not been found by previous groups $(29,31)$. Again, the strict criteria in obtaining serum from all our patients and controls in the fasting state immediately prior to surgery might be a possible reason for our finding. Our findings may be relevant to those of several groups who have recently reported undetectable levels of IGFBP-1 in tumorigenic breast tissue specimens $(21,22)$, and in breast cancer cell lines (7), suggesting a down-regulation of IGFBP-1 synthesis in breast cancer.

The present study did not find any differences in serum total IGF-I or IGF-II levels between our two study groups. However, since IGFBP-3, which is the main IGFBP in serum, and IGFBP-1, which is thought to modulate the free fraction of circulating $\operatorname{IGF}-\mathrm{I}(26,32)$, are both lower, our findings would strongly suggest an increase in the bioavailable IGF-I in patients with breast cancer. This would be consistent with a recent large study of breast cancer (4) and of prostate cancer patients (5) suggesting that IGF-I may be an important factor in cancer risk. There is also evidence to suggest a direct inhibitory role for IGFBP-3 that is independent of IGF-I (10-12) and the lower serum IGFBP-3 concentrations found in the present study may thus be relevant also.

Our novel finding of a significantly higher PSA level would be consistent with previous isolated case reports of elevated serum PSA in breast cancer patients (33). Previous studies have demonstrated the presence of PSA in breast cancer $(15,34)$. The higher serum PSA levels in our breast cancer group of women, compared with our control group, may possibly reflect higher tissue levels, which may increase bioavailable tissue IGF-I, as proteolysis of IGFBP-3 would decrease its binding to IGF-I (13). Our findings of statistically significant correlations between PSA and IGFBP-6, and IGFBP-1, have not been reported previously. Our data allows us to speculate that the elevated PSA levels in the breast cancer cases are related to the decreased binding protein levels, because of the known property of PSA as a binding protein protease. Although previous studies suggest that PSA in serum is probably enzymatically inert, the possibility remains that PSA at the tissue level in breast cancer patients may have IGFBP proteolytic activity.

In conclusion, our study shows that serum levels of PSA were significantly higher, and serum levels of IGFBP-6, -3 and -1 were significantly lower in our breast cancer patients compared with patients with benign breast disease. Although serum IGF-I and -II did not differ between our study groups, it is reasonable to infer that bioavailable IGF-I and IGF-II would be higher in the breast cancer group which may have significant clinical implications. In addition, the novel finding that IGFBP-6 was significantly lower in our breast cancer group of women would suggest that further studies on the role of IGF-II in human breast cancer may be valuable.

\section{Acknowledgements}

This study was supported in part by a research grant from the National Medical Research Council \#219/97 NUS RP 970309 (K-OL, EHN). The results were presented in part as an abstract at the 21st Annual San Antonio Breast Cancer Symposium, San Antonio, TX, USA, December 1998.

\section{References}

1 Cullen KJ. Yee D, Sly WS, Perdue J. Hampton B, Lippman ME et al. Insulin-like growth factor receptor expression and function in human breast cancer. Cancer Research 199050 48-53. 
2 Osborne CK, Coronado EB, Kitten LJ, Arteaga CI, Fuqua SA, Ramasharma $\mathrm{K}$ et al. Insulin-like growth factor II (IGF-II): a potential autocrine/paracrine growth factor for human breast cancer acting via the IGF-I receptor. Molecular Endocrinology 1989 3 1701-1709.

3 Chen JC, Shao ZM, Sheikh MS, Hussain A, LeRoith D, Roberts CT Jr et al. Insulin-like growth factor binding protein enhancement of insulin-like growth factor-I (IGF-I)-mediated DNA synthesis and IGF-I binding in a human breast cancer cell line. Journal of Cell Physiology 1994158 69-78.

4 Hankinson SE, Willett WC, Colditz GA, Hunter DJ, Michaud DS, Deroo B et al. Circulating concentrations of insulin-like growth factor I and risk of breast cancer. Lancet 1998351 1393-1396.

5 Chan JM, Stampfer MJ, Giovanucci E, Gann PH, Ma J, Wilkinson P et al. Plasma insulin-like growth factor-I and prostate cancer risk: a prospective study. Science 1998279 563-566.

6 McCusker RH, Camacho-Hubner C, Bayne ML, Cascieri MA \& Clemmons DR. Insulin-like growth factor (IGF) binding to human fibroblast and glioblastoma cells, the modulating effect of cell released IGF binding proteins (IGFBPs). Journal of Cell Physiology $1990144244-253$.

7 McGuire WL, Jackson JG, Figueroa JA, Shimasaki S, Powell DR \& Yee D. Regulation of insulin-like growth factor-binding protein (IGFBP) expression by breast cancer cells: use of IGFBP-1 as an inhibitor of insulin-like growth factor action. Journal of the National Cancer Institute 199284 1336-1341.

8 Figueroa JA, Lee AV, Jackson JG \& Yee D. Proliferation of cultured human prostate cancer cells is inhibited by insulin-like growth factor (IGF) binding protein-1: evidence for an IGF-II autocrine growth loop. Journal of Clinical Endocrinology and Metabolism 1995 $803476-3482$.

9 Knauer DJ \& Smith GL. Inhibition of biological activity of multiplication-stimulating activity by binding to its carrier protein. Proceedings of the National Academy of Sciences of the USA 198077 7252-7256.

10 Gill ZP, Perks CM, Newcomb PV \& Holly JM. Insulin-like growth factor binding protein-3 (IGFBP-3) predisposes breast cancer cells to programmed cell death in a non-IGF-dependent manner Journal of Biological Chemistry 1997272 25602-25607.

11 Nickerson T, Huynh H \& Pollak M. Insulin-like growth factor binding protein-3 induces apoptosis in MCF-7 breast cancer cells. Biochemical and Biophysical Research Communications 1997237 690-693.

12 Oh Y, Muller HL, Lamson G \& Rosenfeld RG. Insulin-like growth factor (IGF) independent action of IGF-binding protein-3 in Hs578T human breast cancer cells. Cell surface binding and growth inhibition Journal of Biological Chemistry 1993268 14964-14971.

13 Cohen P, Graves HCB, Peehl DM, Kamarei M, Giudice LC \& Rosenfeld RG. Prostate-specific antigen (PSA) is an insulin-like growth factor binding protein-3 protease found in seminal plasma. Journal of Clinical Endocrinology and Metabolism 199175 1046-1053.

14 Cohen P, Peehl DM, Graves HB \& Rosenfeld RG. Biological effects of prostate-specific antigen as an insulin-like growth factor binding protein-3 (IGFBP-3) protease. Journal of Endocrinology 1994142 407-415.

15 Diamandis EP, Yu H \& Sutherland DJA. Detection of prostate specific antigen immunoreactivity in breast tumors. Breast Cancer Research and Treatment 199432 301-310.

$16 \mathrm{Yu} \mathrm{H} \&$ Diamandis EP. Prostate-specific antigen in milk of lactating women. Clinical Chemistry 199541 54-58.

17 Roghani M, Hossenlopp P, LePage P, Ballard A \& Binoux M. Isolation from human cerebrospinal fluid with a new insulin-like growth factor-binding protein with a selective affinity for IGF-II. FEBS Letters 1989255 253-258.

18 Lee KO, Oh Y, Giudice LC, Cohen P, Peehl DM \& Rosenfeld RG. Identification of insulin-like growth factor binding protein-3 (IGFBP-3) fragments and IGFBP-5 proteolytic activity in human seminal plasma. Journal of Clinical Endocrinology and Metabolism $1994791367-1372$.

19 Cullen KJ, Smith HS, Rosen N \& Lippman ME. Insulin-like growth factor messenger RNA expression by human fibroblasts from benign and malignant lesions. Cancer Research 199151 49784985.

20 Yee D, Cullen KJ, Paik S, Perdue JF, Hampton B, Schwartz A et al. Insulin-like growth factor II mRNA expression in human breast cancer. Cancer Research 198848 6691-6698.

21 Pekonen F, Nyman T, Ilvesmaki V \& Partanen S. Insulin-like growth factor binding proteins in human breast cancer tissue. Cancer Research 199252 5204-5207.

22 Manni A, Wei L, Badger B, Zaenglein A, Leighton J, Shimasaki S et al. Expression of messenger RNA for insulin-like growth factors and insulin-like growth factor binding proteins by experimental breast cancer and normal tissue in vivo. Endocrinology 1992130 1744-1746.

23 Howarth DJ, Aronson IB \& Diamandis EP. Immunohistochemical localization of prostate-specific antigen in benign and malignant breast tissues. British Journal of Cancer 199775 1646-1651.

24 Lazaris AC, Theodoropoulos GE, Diamantopoulos AK. Anastassopoulos PD \& Davaris PS. Immunohistochemical detection of cathepsin-D in low grade breast invasive cancer. Anticancer Research 199717 2651-2655.

25 Powell DR, Liu F \& Baker BK. Insulin-like growth factor binding protein- 6 levels are elevated in serum of children with chronic renal failure: a report of the Southwest Pediatric Nephrology Study Group. Journal of Clinical Endocrinology and Metabolism 199782 2978-2984.

26 Kelley K, Oh Y, Gargosky S, Gucev Z, Matsumoto T, Hwa V et al. Insulin-like growth factor binding proteins (IGFBPs) and their regulatory dynamics. International Journal of Biochemistry and Cell Biology 199628 619-637.

27 Corcoran D, Perachiotti A \& Darbre PD. Increased autocrine production of insulin-like growth factor-II (IGF-II) alters serum sensitivity of MCF-7 human breast cancer cell proliferation. Cell Proliferation 199629 479-493.

28 Bruning PF, van Doorn J, Bonfrer JM, Van Noord PA, Korse LM, Linders TC et al. Insulin-like growth factor binding protein-3 is decreased in early-stage operable pre-menopausal breast cancer. International Journal of Cancer 199562 266-270.

29 Del Giudice ME, Fantus IG, Ezzat S, McKeown-Eyssen G, Page D \& Goodwin PJ. Insulin and related factors in premenopausal breast cancer risk. Breast Cancer Research and Treatment $199847111-$ 120.

30 Favoni RE, de Cupis A \& Perrotta A. Insulin-like growth factor-I (IGF-I) and IGF-binding proteins blood serum levels in women with early- and late-stage breast cancer: mutual relationship and possible correlations with patients' hormonal status. Journal of Cancer Research and Clinical Oncology 1995121 674-682.

31 Lonning PE, Helle SI, Johannessen DC, Adlercreutz H, Lien EA, Tally M et al. Relations between sex hormones, sex hormone binding globulin, insulin-like growth factor-I and insulin-like growth factor binding protein-1 in post-menopausal breast cancer patients. Clinical Endocrinology 199542 23-30.

32 Lewitt MS, Saunders H, Cooney GJ \& Baxter RC. Effect of human insulin-like growth factor binding protein-1 on the half-life and action of administered insulin-like growth factor-I in rats. Journal of Endocrinology $1993136253-260$.

33 Borchert GH \& Diamandis EP. Elevated levels of prostate-specific antigen in serum of women with fibroadenomas and breast cysts. Journal of the National Cancer Institute 199789 587-588.

34 Melegos DN \& Diamandis EP. Diagnostic value of molecular forms of prostate-specific antigen for female breast cancer. Clinical Biochemistry 199629 193-200.

Received 9 September 1998

Accepted 13 November 1998 